\title{
Comparison of heavy metal and nutrients removal in Canna indica and Oryza sativa $L$. based constructed wetlands for piggery effluent treatment in north-central Nigeria
}

\author{
Olamide Olawale, Davids O. Raphael, Christopher O. Akinbile \& Kater Ishuwa
}

To cite this article: Olamide Olawale, Davids O. Raphael, Christopher O. Akinbile \& Kater Ishuwa (2021): Comparison of heavy metal and nutrients removal in Canna indica and Oryza sativa L. based constructed wetlands for piggery effluent treatment in north-central Nigeria, International Journal of Phytoremediation, DOI: 10.1080/15226514.2021.1900062

To link to this article: https://doi.org/10.1080/15226514.2021.1900062

\section{曲 Published online: 22 Mar 2021.}

Submit your article to this journal $₫$

View related articles $\longleftarrow$

View Crossmark data $\nearrow$ 


\title{
Comparison of heavy metal and nutrients removal in Canna indica and Oryza sativa $L$. based constructed wetlands for piggery effluent treatment in north-central Nigeria
}

\author{
Olamide Olawale ${ }^{\mathrm{a}}$, Davids O. Raphael ${ }^{\mathrm{b}}$ (D), Christopher O. Akinbile ${ }^{\mathrm{b}, \mathrm{c}}$, and Kater Ishuwa ${ }^{\mathrm{a}}$ \\ ${ }^{a}$ Department of Chemical Engineering, Landmark University, Omu-Aran, Nigeria; ${ }^{b}$ Department of Agricultural and Biosystems Engineering, \\ Landmark University, Omu-Aran, Nigeria; 'Department of Agricultural and Environmental Engineering, Federal University of Technology \\ Akure, Akure, Nigeria
}

\begin{abstract}
Batch-fed horizontal sub-surface flow constructed wetlands (HssFCW) were developed to compare the potential of Canna indica and Oryza sativa $L$. in removing heavy metals and nutrients from piggery effluent. Piggery effluent samples were characterized for nutrients ( $N$ and $P$ ) and metals ( $\mathrm{Mg}, \mathrm{Al}, \mathrm{Ca}$ and $\mathrm{Fe}$ ) before and after introducing them to the HssFCW with hydraulic retention time (HRT) of 3 days and operational flowrate of $0.014 \mathrm{~m}^{3} /$ day. Three sets of constructed wetlands (CWs) were monitored during the dry season for 3 months. The bioconcentration factor (BCF) and translocation factor (TF) for the plants were evaluated. The results were all significantly different at $p \leq 0.05$. O. sativa $L$ removes more nutrients and metals than $C$. indica. The BCF for $O$. sativa $L$. was higher than for $C$. indica, while the TF for $C$. indica was higher for $O$. sativa $L$., indicating a higher metal translocation potential. Use of $C$. indica, a non-food crop, poses no health risks in HssFCWs whereas the grains of $O$. sativa $L$. are consumed directly by humans, presenting potential risks when used in HssFCWs. Compared to an annual O. sativa L., the perennial $C$. indica can be grown continuously in CWs for the phytoremediation of piggery effluent.

\section{NOVELTY STATEMENT}

- No known work about the phytoremediation potential of the two studied macrophytes in the agro-ecological zone is known. The study also provides insight into the bioconcentration of metals in the edible part of Oryza sativa L. FARO 44 (SIPI 692033).

- The characterization of piggery effluent revealed that its compositions were above the allowable limit for reuse and recycling despite the adoption of low-water use intensive method.

- The study showed that Oryza sativa $L$ accumulates more metals in the above-ground tissues than in its root and provide insight into its use as a phytoremediation plant in the study area.

- The footprint of pollutants and metals in Oryza sativa $L$ makes a perennial $C$. indica more suitable than $O$. sativa $L$. in piggery effluent phytoremediation.
\end{abstract}

\section{KEYWORDS}

Canna indica; Oryza sativa L.; piggery effluent; bioconcentration; metals

\section{Introduction}

Piggery farms generate a large volume of effluents of varying quantity and quality worldwide. Intensive pig production results in substantial wastewater production. Generally, piggery effluent is a high strength effluent with elevated levels of organic solids, nutrients, metals and possibly salts in both dissolved and particulate forms (Velho et al. 2012). Direct release of piggery wastewater can result in eutrophication of nearby water bodies or soil contamination because of nitrate infiltration (Huang et al. 2013). However, some contaminants like nitrogen $(\mathrm{N})$ and phosphorus $(\mathrm{P})$ may be a source of good nutrients for agricultural production, biogas and increasing soil fertility (Tokhun et al. 2010; MolinuevoSalces et al. 2016). The raw effluent quantity and quality is determined by feed types and pen management practices.
Traditional piggery effluent treatments methods entail solid-liquid separation followed by biological methods (aerobic and anaerobic) in bioreactors and biofilters, treatment in biodigester and stabilization ponds depending on the characteristics of the effluent (Girard et al. 2014). Biological methods have proven to be more suitable due to the richness of effluent in nutrients and elements that support the growth of microbes like algae. The sludge is usually disposed of by converting them to fertilizer for soil amendment. Common heavy metals and nutrients found in piggery effluent are $\mathrm{Zn}, \mathrm{Cu}$,

$\mathrm{Pb}, \mathrm{Cd}$ and metals like $\mathrm{Mg}, \mathrm{Al}, \mathrm{Ca}$ and Fe. They are mostly introduced through the feed. Lee et al. (2010) reported influent mean concentration values of $(146.2 \pm 46.7) \mathrm{mg} / \mathrm{L}$, and $(5.5 \pm 2.1) \mathrm{mg} / \mathrm{L}$, for total nitrogen 
and phosphorus respectively from a secondary piggery wastewater effluent in Korea. Concentration values of heavy metals of $0.093 \pm 0.001,0.0002 \pm 0.001,0.022 \pm 0.001$ and $0.0360 \pm 0.003$ were reported for a large-scale piggery farm in Thailand (Tokhun et al. 2010). There have been few studies on the broader metal contents of piggery effluent at the time of this study; most studies have focused on piggery effluents containing heavy metal contents and organic pollutants.

Phytoremediation uses plants to extract and detoxify or degrade chemical compounds including nutrients, metals, organic and inorganic pollutants from the soil and wastewater (Raphael, Okunade, et al. 2020). Various macrophytes have been tested as phytoremediators to purify wastewater (Zhang et al. 2015; Schierano et al. 2018). Plants used have special features, that allow them to absorb and accumulate pollutants into their roots or precipitate them in the rhizosphere (Karczewska et al. 2013). Metals are usually of great concern as they are mostly removed by physico-chemical methods like adsorption, precipitation, ion exchange, etc. (Soda et al. 2012). Phytoremediation of piggery effluent in CWs is solar energy driven, can be potentially cost-effective and enhances natural processes. The system is adaptable for handling large volumes of effluent with a wide range of pollutants per time. These outweigh the challenges of large space requirements, utilization and disposal of contaminated plants biomass and long HRT requirements.

Plants used in phytostabilization can gather pollutants round the plant rhizosphere, hence, reducing the migration of toxic metals to other areas (Thakur et al. 2016). Such plants can be subsequently harvested, processed and disposed of (Vymazal 2013). Few Parameters are commonly used in describing the ability of plants to extract or stabilize metals in the soil include BCF (bioconcentration factor), and TF (translocation factor). Plants with a high bioconcentration factor $(\mathrm{BCF}>1)$ and, at the same time, with a low translocation factor $(\mathrm{TF}<1)$ are potentially suitable for phytostabilization and have relatively high phytoaccumulation capabilities (Korzeniowska and Stanislawska-Glubiak 2015). The TF value is an important indicator that is commonly used to evaluate the potential of the plant for phytoremediation, as larger TFs imply higher translocation capability (Soda et al. 2012; Ng et al. 2016).

Canna indica is an ornamental plant that has been used as a phytoremediation plant. The plant has a single stem with broad leaves and can grow to about $0.5-2.5 \mathrm{~m}$ high. It also can live on wastewater. Many researchers have found the ornamental plant to be highly effective in the treatment of different wastewater types (Subhashini and Swamy 2014). The $C$. indica effectively translocated lead and chromium to aerial parts while the roots retain high quantities of cadmium, nickel and zinc in a study by Subhashini et al. (2013). O. sativa L. planted CWs have been tried in Brazil. The system was fed daily with water from a nearby urban stream polluted with sewage (Meira et al. 2013). The CW technology has been described as a reliable, effective and feasible solution for wastewater treatment (Stefanakis and Tsihrintzis 2012). A tropical region is where all-year-round plant growth and microbiological activity is supported by warmer weather and has a positive effect on treatment parameters compared to temperate conditions. The continuous warm temperature and intense sunlight in the tropics promote rapid, year-round growth of macrophytes and can lead to significant aquatic macrophyte uptake of wastewater nutrients as reported by Zhang et al. (2015).

The objective of the study was to select the best of the two indigenous macrophytes ( $C$. indica and $O$. sativa $L$.) in the removal of heavy metals and nutrients from piggery effluent in a tropical climate in a phytoremediation study in an HssFCW. The common methods of treating piggery wastewater as reported were aerobic and anaerobic lagoons, ponds and recent studies have been on the use of CW technologies (Adrados et al. 2014). Not much study is known of the phytoremediation potential of $C$. indica and $O$. sativa $L$. treating piggery effluent in the tropics. Both plants are found in abundance (wild and planted) in the study area because of their adaptation to the high daily temperature in the region. The comparative study will provide insight into metal and nutrients removal by the two indigenous macrophytes in the study area to adopt the one with a desirable attribute of BCF and TF. Heavy metals like $\mathrm{Cu}$ and $\mathrm{Zn}$ are intentionally added to piggery feed to promote growth, prevent diarrhea and to enhance the immune systems of pigs (Zhang et al. 2012). These are later excreted by pigs, pigs, thereby increasing the heavy metal loads of piggery effluent. Effective wastewater treatment has numerous benefits such as environmental protection, public health improvement and treated water recycling (Remy et al. 2017).

\section{Materials and methods}

\section{The study area}

This study was carried out at the Landmark University, Omu-Aran. It lies in the humid plain agro-ecological zone of the southern guinea savannah of north-central Nigeria. Omu-Aran is on latitude $88^{\prime} 00^{\prime \prime} \mathrm{N}$ and longitude $5^{\circ} 6^{\prime} 00^{\prime \prime} \mathrm{E}$, at an altitude of $564 \mathrm{~m}$ above sea level. The map of the study site state relative to Nigeria is shown in Figure 1. The climate is a tropical maritime with a long rainy season and characterized by moderate weather with an annual daily average temperature range from 16 to $32^{\circ} \mathrm{C}$ and an average annual rainfall of $1000-1150 \mathrm{~mm}$ spread over 6-8 months. (Raphael, Okunade, et al. 2020). The pen housed 25 pigs with an average weight of $80 \mathrm{~kg}$. Pig manure and daily yard washings passed through the floor of the pen into a drain and were collected in a lined excavated pit serving as a holding tank where the slurry underwent some sedimentation. The average amount of raw effluent from the holding tank generated daily was about $5-6 \mathrm{~m}^{3}$.

\section{Piggery effluent sampling and characterization}

The qualitative characterization of the piggery effluent was performed by sampling and analysis of effluent from the drains beside the piggery. Piggery effluent samples were collected and 

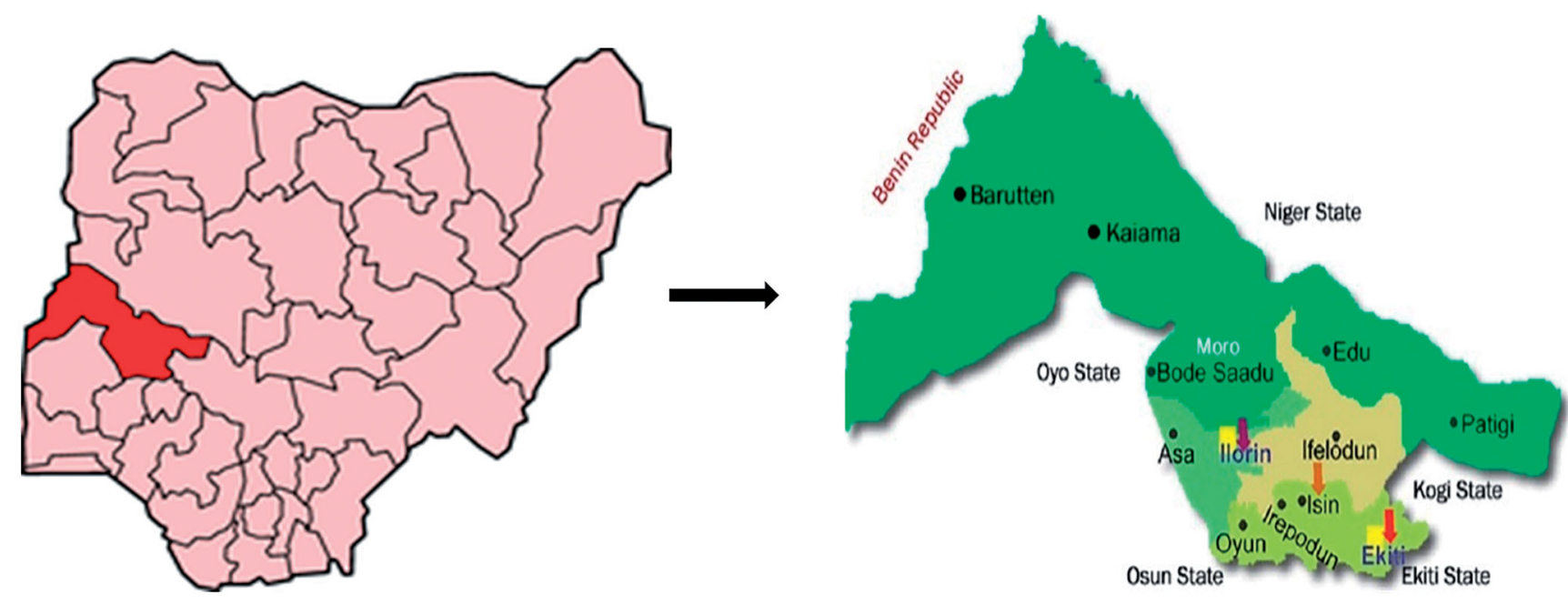

Figure 1. Map of Nigeria showing the study location (Irepodun). Source: Elemile et al. 2019.

characterized for physico-chemical parameters, like BOD5, total dissolved solids (TDS), $\mathrm{pH}$, electrical conductivity (EC), total nitrogen $(\mathrm{N})$, total phosphorous $(\mathrm{TP})$, metals $(\mathrm{Mg}, \mathrm{Al}, \mathrm{Ca}$ and $\mathrm{Fe}$ ) and sodium adsorption ratio (SAR). These analyses were performed by Standard Methods for the Examination of Water and Wastewater (APHA 2005). Monitoring consisted of the collection of 7 sets of samples fortnightly during the investigation period with 3 replicates each. The average values of each of the three different samples were taken as the value of the parameter for the sample. A grab sampling was done manually in sterile bottles for further analysis in the environmental laboratory in Landmark University for every batch of samples taken. Sampling was done early in the morning to avoid interference of the ambient temperature with the dissolved oxygen in wastewater. The volume of samples collected was based on the parameters and the number of analyses needed. Samples were preserved in the chest box with ice for preservation. Parameters including dissolved oxygen (DO), $\mathrm{pH}$ and EC were determined in the field using portable instruments (Multi-function meter-WA-2015). TN and TP were tested using the colorimetric, Palintest Photometer 7100 method. Total dissolved solids (TDS) were measured using the gravimetric method following oven drying. The biochemical oxygen demand (BOD5) analyses were done using dilution methods and comparing the DO before and after five days of incubation. Metals ( $\mathrm{Fe}$ and $\mathrm{Al}$ ) were analyzed using an atomic absorption spectrometer (AAS SearchTech AA320N, UK). Ethylenediaminetetraacetic acid (EDTA) complexometric titration method was used for the determination of $\mathrm{Ca}$, and $\mathrm{Mg}$ while SPSS Flame Photometer (Model PFP7, Jen way, England) was used for Na. The sodium adsorption ratio (SAR) was determined using Equation (1) in Raphael, Ogedengbe, et al. (2020). The $\mathrm{pH}$ and EC were determined on the field using portable instruments (Multi-function meter-WA-2015).

\section{Pretreatment and treatment unit description}

The pretreatment started with the detention of the effluent in a lined excavated pit before the effluent was pumped into a holding tank where dirt and suspended solids from the piggery dung and food materials were removed by a 100 micro polyesters filter cloth. The pretreated piggery effluent was then made to flow through layers of a sand-gravel filter system. The pilot-scale HssFCWs were constructed from $210 \mathrm{~L}$ oil drums with a diameter of $600 \mathrm{~mm}$ and a height of $850 \mathrm{~mm}$. Two pilot-scale CWs were formed from a single polyethylene drum (PE) split longitudinally into 2 halves. The plastic wetlands used in the experiment and the fullygrown plants are shown in Figure 1. The capacity of each plastic trough was about $105 \mathrm{~L}$. The bed depth of the planting medium was $0.2 \mathrm{~m}$. From bottom to top, the first layer of $50 \mathrm{~mm}$ consisted of granite aggregates of size $12-15 \mathrm{~mm}$ and was made to cover the drainage pipe (diameter $50 \mathrm{~mm}$ ) located at the bottom of each CW cell to enhance an effluent collection. The second layer above the first was of $150 \mathrm{~mm}$ coarse sand of size $1-2 \mathrm{~mm}$ and porosity of $45 \%$ and Darcy's conductivity of $0.34 \mathrm{~m} \mathrm{~d}^{-1}$, into which the macrophytes were planted. Lastly, a freeboard of $50 \mathrm{~mm}$ was allowed to prevent the spilling of water from the $\mathrm{CW}$ tanks as in Raphael et al. (2019). The batch-flow CWs were operated with a hydraulic retention time (HRT) of 3 days and an operation flow rate of $0.014 \mathrm{~m} 3 /$ day. Nine cells of three sets of treatment wetlands were developed for two different plants and the third set designated as the control unit as shown in Figure 2.

Healthy young $C$. indica plants were uprooted from a residential garden unpolluted with metals in Omu-Aran town and washed with clean tap water. The $C$. indica shoots were trimmed to $10 \mathrm{~cm}$ and transplanted in each of the CWs at a density of 15 plants per square meter. The nursed FARO 44 (SIPI 692033) low-land rice (Oryza sativa. L) variety was collected from a rice plantation field and transplanted after 7 weeks of sowing into the second CW. The macrophytes were cultivated under irrigation with piggery effluent during the dry season of 2018/2019 (5th December to 13th March). The third CW was left unplanted and was designated as a control. The three CWs were replicated thrice. After transplanting, clean tap water was applied to the system continuously for 7 weeks until the plants were fully established. The piggery effluent was collected and 
(a)

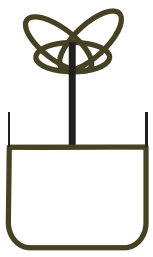

(c)
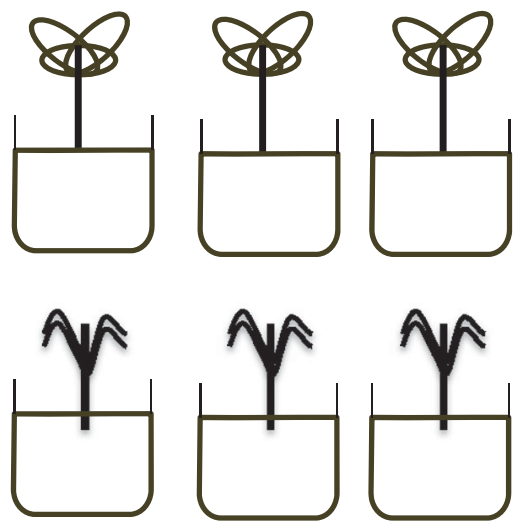

(d)

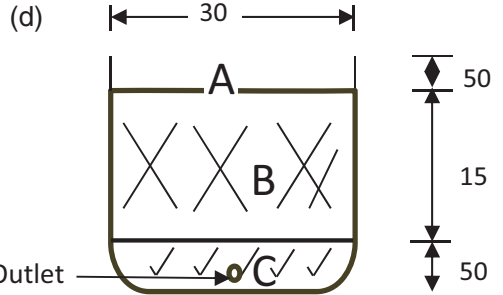

(b)

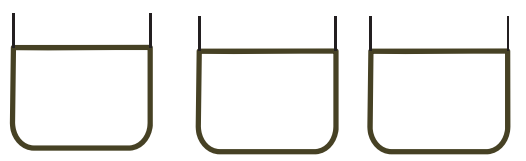

5

Figure 2. The sketch of the experimental setup (a) CWs planted with Canna indica, (b) CWs planted with Oryza sativa L, (c) unplanted CWs, (d) CW substrate layers, A-freeboard; B-coarse sand layer; C-granite aggregate.

analyzed for various parameters before feeding it into the CWs. The piggery effluent was allowed to remain within the CWs for 3 days (HRT) after which the treated water samples were collected and analyzed in the laboratory for the same sets of parameters earlier tested.

\section{Macrophyte growth and tissue analysis}

The two macrophytes which were trimmed to the same height during transplanting were monitored weekly by measuring the plant height of three tagged plants in the different CW units except for the control units which was unplanted. All results were reported as weekly averages. The monitoring period lasted for the entire duration of the experiment (4 months). Samples of unpolluted plant materials were tested for metals at the beginning of the experiment. At the end of the experiment, all plants were harvested, washed thoroughly with tap water and rinsed with deionized water and prepared for tissue analysis. The selected plants were weighed using a digital electronic scale, $\pm 0.1 \mathrm{~g}$ accuracy. The plants were then divided into roots (below ground), stem and leaves/paddy in the case of $O$. sativa. L (above ground). The samples were dried at $80^{\circ} \mathrm{C}$ for 24 hours (oven) and ground with a crushing machine. Approximately, $0.5 \mathrm{~g}$ of sample material was digested in $10 \mathrm{ml}$ of $\mathrm{HNO}_{3}$ (65\%). Samples were filtered using Whattman filter paper (No. 45) and the metal content in the filtrate was determined using the atomic absorption spectrophotometer (AAS SearchTech AA320N, UK) as in the study by Hussain et al. (2019).

\section{Concentration and translocation of metals in plants}

The Bioconcentration factor $(B C F)$ was calculated as the ratio of metal concentration in the whole plant tissue and the metal concentration in water as determined in MaderaParra et al. (2015).

$$
B C F=C_{P} / C_{W}
$$

Where $\mathrm{BCF}$ is in $(\mathrm{L} / \mathrm{kg}), \mathrm{C}_{P}$ is the metal concentration in the whole plant tissue $(\mathrm{mg} / \mathrm{kg}-\mathrm{DW})$ and $\mathrm{C}_{W}$ is the metal concentration in wastewater $(\mathrm{mg} / \mathrm{L})$. A large value of $B C F$ implies a better phytoaccumulation capability.

The translocation factor (TF) was calculated by dividing the metal concentrations in above-ground tissues by those accumulated in the root tissues. The TF values were calculated according to the formula given by Soda et al. (2012) as in Equation (2).

$$
\mathrm{TF}=\mathrm{C}_{\mathrm{I}} / \mathrm{C}_{\mathrm{R}}
$$

Where, $\mathrm{C}_{\mathrm{I}}$ is the metal concentration in the above-ground tissue $(\mathrm{mg} / \mathrm{kg}-\mathrm{DW})$, and $\mathrm{C}_{\mathrm{R}}$ is the metal concentration in the roots $(\mathrm{mg} / \mathrm{kg}-\mathrm{DW})$. TF values higher than $1(\mathrm{TF} \gg 1)$, implies a higher translocation capability (Ali et al. 2013).

\section{Removal efficiency (RE)}

The RE of pollutants was calculated to determine their potential uptake by $C$. indica and $O$. sativa $L$. using Equation 3 (Darajeh et al. 2014).

$$
\text { Removal efficiency }(\%)=\frac{C_{i n}-C_{o u t}}{C_{i n}} \times 100
$$

Where $C_{i n}$ and $C_{\text {out }}$ is the inflow concentration and outflow concentration, respectively $(\mathrm{mg} / \mathrm{l})$.

\section{Statistical analysis}

The obtained data were analyzed statistically. The measurements were expressed in terms of mean values and standard errors for duplicates. A one-way ANOVA was performed on the RE and heavy metal accumulation data sets in the plants. All statistical analyses were carried using the SPSS 22 software package and the excel tool. The significant difference of the results between $C$. indica and $O$. sativa $\mathrm{L}$. treatments were assessed at 5\% probability level. Tukey's statistic was used to determine which means are significantly different from the others. Each experiment was done in three replicates and the result expressed as mean \pm SE. 


\section{Results and discussion}

\section{Piggery effluent characterization}

The quality of piggery effluent is shown in Table 1. The sources of piggery effluent were mainly from cleaning wash water, drinking water mixed with urine and other cleaning services in the pen. The EC, SAR and TDS values were found to be high; this is an indication of high salinity of the effluent from the livestock trade wastewater. SAR measures the relative concentration of sodium $\left(\mathrm{Na}^{+}\right)$to calcium $\left(\mathrm{Ca}^{2+}\right)$ and Magnesium $\left(\mathrm{Mg}^{2+}\right)$. The high SAR concentration value indicates that the piggery wastewater will impact soil structural ability if used untreated (Idris et al. 2012). The $\mathrm{pH}$ was within the range of 7.7-8.5 which is typical of an alkaline solution due to the mixture of the washing detergent, feed and urine of the pigs. The composition of the piggery effluent also shows that the metals were minimal, and the organic content was very low. The nutrients were also low, probably due to a few heads of animals, and the cleaning is not done by spraying water frequently but by sweeping of the housing, which reduces the amount of swine dung that is flushed down the drain and later turned into wastewater. The pen is usually swept first. That reduces the volume of effluent generated daily, consequently, lowstrength organic waste. The same process also affects the concentration of other pollutants in the sampled effluent. The metals were below WHO limits for reuse (WHO 2006).

\section{Removal of EC, SAR, TDS, and $p H$}

The removal efficiency (RE) values of planted and unplanted HssFCW are shown in Table 2. It can be seen that the

Table 1. Characteristics of piggery effluent in the study site $(n=7)$.

\begin{tabular}{llcc}
\hline Parameter & Unit & Range & Average \pm SE* $^{*}$ \\
\hline EC & $\mu S / c m$ & $153.5-782.0$ & $305.0 \pm 89.2$ \\
$\mathrm{TN}$ & $\mathrm{mg} / \mathrm{L}$ & $1.2-10.6$ & $4.5 \pm 1.3$ \\
$\mathrm{TP}$ & $\mathrm{mg} / \mathrm{L}$ & $0.3-3.1$ & $1.0 \pm 0.4$ \\
$\mathrm{pH}$ & & $7.7-8.5$ & $7.9 \pm 0.1$ \\
$\mathrm{SAR}$ & & $25.4-184.4$ & $74.5 \pm 21.6$ \\
$\mathrm{TDS}$ & $\mathrm{mg} / \mathrm{L}$ & $76.7-391.0$ & $152.6 \pm 44.6$ \\
$\mathrm{BOD}$ & $\mathrm{mg} / \mathrm{L}$ & $2.0-34.0$ & $18.4 \pm 5.1$ \\
$\mathrm{Al}$ & $\mathrm{mg} / \mathrm{L}$ & $0.1-1.1$ & $0.3 \pm 0.2$ \\
$\mathrm{Fe}$ & $\mathrm{mg} / \mathrm{L}$ & $0.2-2.0$ & $1.1 \pm 0.3$ \\
$\mathrm{Mg}$ & $\mathrm{mg} / \mathrm{L}$ & $3.0-26.0$ & $17.0 \pm 3.9$ \\
$\mathrm{Ca}$ & $\mathrm{mg} / \mathrm{L}$ & $5.0-32.0$ & $13.8 \pm 4.8$ \\
\hline
\end{tabular}

*SE: standard error obtained for 3 replicates. percentage removal of EC was better in $C$. indica followed by $O$. sativa $L$. and then the unplanted system recorded the least. The same trend was seen in SAR and TDS. The total dissolved solids (TDS) is related to the ability of the material to conduct electricity, hence, TDS removal is correlated to EC. The $O$. sativa $L$. removed more TDS than $C$. indica and unplanted system in that order. This can be attributed to $O$. sativa L's ability to remove some metals from the aqueous solution as part of its requirements for growth (micronutrients). This, in turn, affects the number of free ions and TDS. Whenever the unplanted CW performs better than any planted system it is due to the photodegradation of pollutants which has been aided by the high temperature and sunshine in the study area. The $C$. indica has a higher potential of accumulating ions than $O$. sativa $L$. due to its rhizomatous rootstock and high biomass production and growth rates which is different for the fibrous root of $O$. sativa L (Chen et al. 2009; Haritash et al. 2015). The rhizomes reduce the filtration ability of the substrate matrix to some extent, hence, low RE for TDS. Also, TDS is mostly removed by physical adsorption which depends on the capacity of the adsorbent that can reach saturation capacity with time. The adsorbent capacity of $C$. indica is limited as it is a poor hyperaccumulator compare to $O$. sativa $L$ which continuously transfer dissolved ion to aerial tissues. This agrees with the findings of Klink et al. (2013) in which the majority of metals detection was in the rhizomes of Typha latifolia L. The statistical differences and p-value obtained from the ANOVA calculation show that the results from the planted and unplanted treatment were all significantly different (Table 2). There is a correlation between EC, SAR and TDS and temperature (Oyem et al. 2014). Hence, they behave the same way in the treatment system. The planted systems have a shade that reduces the temperature of the substrate. The $\mathrm{pH}$ removal efficiency for unplanted systems was found to be low and within the acceptable limit of $6-9$. The $\mathrm{pH}$ is related to the concentration of ions in a solution. The uptake of metal by plants is usually low since they are required in a low quantity for plant growth. This agrees with the findings of Udom et al. (2018) that reported a low value of $\mathrm{RE}$ for $\mathrm{pH}$ in a pilot-scale $\mathrm{HssFcW}$ planted with Pennisetum spp treating piggery wastewater. The reason is that the influent $\mathrm{pH}$ of 7.9 was in the alkaline region and not many changes are expected. This agrees with the

Table 2. Removal efficiency value of planted and unplanted HssFCW systems $(n=7)$.

\begin{tabular}{|c|c|c|c|c|c|}
\hline Parameters & Unit & $\begin{array}{c}\text { Canna indica } \\
\text { Average } \pm \text { S.E }(\%)\end{array}$ & $\begin{array}{c}\text { Oryza sativa } L . \\
\text { Average } \pm \text { S.E }(\%)\end{array}$ & $\begin{array}{c}\text { Unplanted } \\
\text { Average } \pm \text { S.E (\%) }\end{array}$ & p-Value* \\
\hline$\overline{\mathrm{EC}}$ & $\mu \mathrm{S} / \mathrm{cm}$ & $51.0 \pm 4.0^{c}$ & $35.3 \pm 12.9^{b}$ & $29.6 \pm 5.0^{a}$ & 0.000 \\
\hline $\mathrm{TN}$ & $\mathrm{mg} / \mathrm{L}$ & $66.4 \pm 6.9^{b}$ & $65.2 \pm 4.7^{b}$ & $57.0 \pm 3.4^{\mathrm{a}}$ & 0.018 \\
\hline $\mathrm{TP}$ & $\mathrm{mg} / \mathrm{L}$ & $72.0 \pm 9.0^{b}$ & $75.5 \pm 3.6^{b}$ & $52.3 \pm 4.5^{\mathrm{a}}$ & 0.000 \\
\hline $\mathrm{pH}$ & & $8.4 \pm 2.0^{b}$ & $6.0 \pm 1.9^{b}$ & $1.8 \pm 0.4^{\mathrm{a}}$ & 0.001 \\
\hline SAR & & $10.2 \pm 3.1^{b}$ & $6.0 \pm 0.9^{\mathrm{ab}}$ & $5.1 \pm 3.5^{\mathrm{a}}$ & 0.045 \\
\hline TDS & $\mathrm{mg} / \mathrm{L}$ & $18.9 \pm 1.3^{b}$ & $20.2 \pm 4.9^{b}$ & $15.8 \pm 4.3^{\mathrm{a}}$ & 0.003 \\
\hline BOD & $\mathrm{mg} / \mathrm{L}$ & $26.5 \pm 2.7^{b}$ & $29.5 \pm 1.6^{b}$ & $16.5 \pm 3.0^{\mathrm{a}}$ & 0.001 \\
\hline $\mathrm{Al}$ & $\mathrm{mg} / \mathrm{L}$ & $41.8 \pm 6.4^{\mathrm{a}}$ & $57.7 \pm 6.8^{b}$ & $55.7 \pm 1.8^{b}$ & 0.000 \\
\hline $\mathrm{Fe}$ & $\mathrm{mg} / \mathrm{L}$ & $59.2 \pm 4.11^{b}$ & $69.2 \pm 2.4^{c}$ & $50.8 \pm 2.1^{\mathrm{a}}$ & 0.000 \\
\hline $\mathrm{Mg}$ & $\mathrm{mg} / \mathrm{L}$ & $66.9 \pm 7.8^{\mathrm{b}}$ & $77.0 \pm 1.3^{c}$ & $50.0 \pm 1.3^{\mathrm{a}}$ & 0.001 \\
\hline $\mathrm{Ca}$ & $\mathrm{mg} / \mathrm{L}$ & $66.4 \pm 7.1^{\mathrm{b}}$ & $79.0 \pm 3.9^{c}$ & $55.6 \pm 1.4^{\mathrm{a}}$ & 0.001 \\
\hline
\end{tabular}

* Significant difference between the plant types and unplanted at $p<0.05$. SE: standard error. Different superscript (letters) indicates a significant difference effect among treatment $(p \leq 0.05)$ using Tukey statistics. 


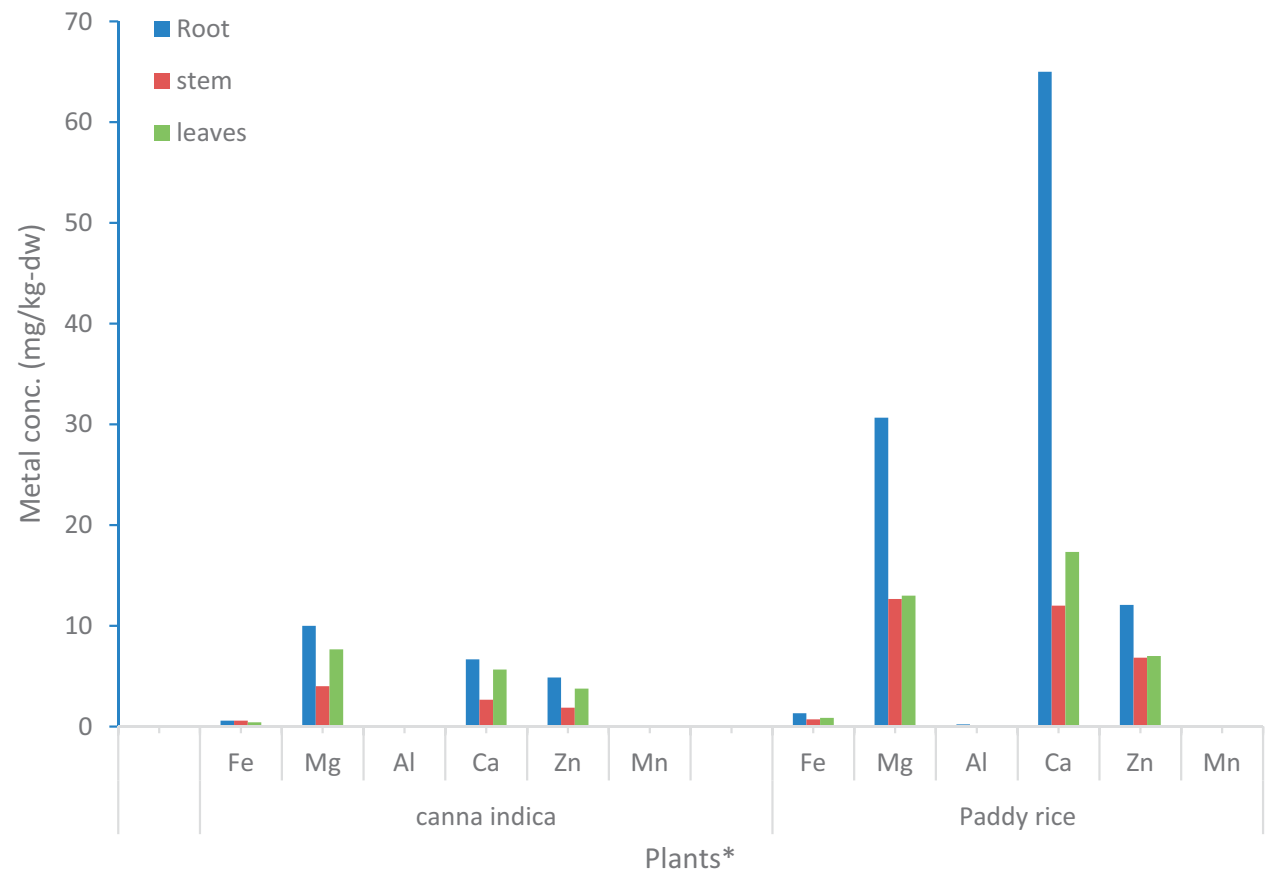

Figure 3. The distribution of metals in different parts of plants. (*Rice head/grain was tested instead of leaves also paddy rice is the same plant as Oryza sativa L.). Fe: Iron; Mg: Magnesium; Al: Aluminum; Ca: calcium; Zn: Zinc; Mn: Manganese.

findings of Haghshenas-Adarmanabadi et al. (2016) in which treated effluent $\mathrm{pH}$ was close to the influent $\mathrm{pH}$.

\section{Removal of nutrients $N, P$}

Piggery wastewater from the study has a low concentration of nutrients. However, a high percentage of REs were recorded for $C$. indica, $O$. sativa $L$. and the unplanted system. $C$. indica was ahead of $O$. sativa $L$. even though the differences were significant $(p=0.018)$ and $(p=0.000)$ for both $\mathrm{N}$ and $\mathrm{P}$. Macrophytes are known to be rapidly growing plants that depend on a high amount of nutrients for their vegetative development. O. sativa $L$. feed more on nutrients than $C$. indica with rapid growth to show for it unlike $C$. indica that stores nutrients more in its root system for future use (Chen et al. 2007; Lai et al. 2011). O. sativa L. and $C$. indica both have root systems that allow them to easily extract nutrients. $C$. indica proved to be better for this study. $O$. sativa $L$. has higher above-ground growth rate compared to $C$. indica with the high below-ground growth rate. $O$. sativa $L$. is known to handles waterlogging stress by forming Lysigenous aerenchyma and a barrier to $\mathrm{O}_{2}$ loss in roots to supply $\mathrm{O}_{2}$ to the root tip (Nishiuchi, et al. 2012). This also further promotes aerobic nitrification condition. In HssFCWs, denitrification processes have been reported to remove up to $60-70 \%$ of the total removal nitrogen and $20-30 \%$ of that is derived from plant uptake (Xu-jie 2013) which is not different from the observed data.

\section{Removal of organics BOD}

The BOD removal value for O. sativa $L$. was better than that of $C$. indica and the unplanted system as shown in Table 2. This is in accordance with past works (Wurochekke et al. 2014; Haghshenas-Adarmanabadi et al. 2016; Udom et al. 2018). Idris et al. (2012) reported that no significant difference was observed for $\mathrm{BOD}_{5}$ removal for both planted and unplanted HssFCW which is different from the findings in this study. $\mathrm{BOD}_{5}$ removal is through absorption, microbial metabolism and sedimentation. Oxygen supply through its root to the root zones assists its system in the removal of BOD than it was recorded for $C$. indica. The result was supported by the finding of Nishiuchi, et al. (2012) on mechanisms for coping with submergence and waterlogging in rice.

\section{Removal of metals $\mathrm{Al}, \mathrm{Fe}, \mathrm{Mg}, \mathrm{Ca}$}

The metals were better removed by $O$. sativa $L$. than $C$. indica system. Yap et al. (2009) reported that metals like Al, $\mathrm{Fe}, \mathrm{Mg}$ and $\mathrm{Ca}$ were found abundantly in $O$. sativa $L$. because they are required for various enzymes activities and play important roles in the photosynthesis and growth of the plant. Hence, higher RE values were recorded in $O$. sativa $L$. compared to $C$. indica and the unplanted system. The fibrous root system with several branching roots in all directions in paddy helps it in trapping ions from within the CW substrate compared to the $C$. indica rhizome which is a horizontal stem. Hence, a better performance by $O$. sativa $L$. with a fibrous root system. The acidic nature of root exudates from O. sativa L. (Bhattacharyya et al. 2013) increases the plant's affinity for metal absorption compared to C. indica. In the case of $\mathrm{Al}$ with higher $\mathrm{RE}$ for the unplanted system than $C$. indica planted system, the mechanism for metal removal can be binding to the soil, sedimentation and precipitation, and adsorption. In the absence of vegetation, $\mathrm{Al}$ could have been removed by binding to the soil. 
Table 3. Bioconcentration factor and translocation factor of metals in C. indica and $O$. sativa $L$.

\begin{tabular}{llllll}
\hline & \multicolumn{2}{c}{ Canna indica } & & \multicolumn{2}{c}{ Oryza sativa L. } \\
\cline { 2 - 3 } \cline { 6 - 6 } Metal & BCF & TF & & BCF & TF \\
\hline $\mathrm{Fe}$ & 1.1 & 0.7 & & 2.1 & 0.7 \\
$\mathrm{Mg}$ & 1.0 & 0.8 & & 2.7 & 0.4 \\
$\mathrm{Al}$ & 0.2 & 0.6 & & 0.7 & 0.3 \\
$\mathrm{Ca}$ & 0.9 & 0.9 & & 5.5 & 0.3 \\
$\mathrm{Zn}$ & 0.4 & 0.8 & & 1.0 & 0.6 \\
$\mathrm{Mn}$ & 0.7 & 0.8 & & 1.7 & 2.3 \\
\hline
\end{tabular}

\section{Bioconcentration and translocation factors in the studied plants}

No toxic symptoms were observed in the two studied plants. The distribution of metals in different parts of plants is shown in Figure 3. The concentration of metals like Fe, Al, $\mathrm{Mn}$, and Ca was low in plant tissues due to their low concentration in the influent. The concentration of metals for both $C$. indica and $O$. sativa $L$. was in the order of root $>$ leaf $>$ stem. The values of calculated $\mathrm{BCF}$ and $\mathrm{TF}$ are shown in Table 3.

The BCF for $O$. sativa $L$. was higher than that of $C$. indica which indicates that $O$. sativa $L$. has better metal accumulation capacity, especially when the concentration of the metals in the wastewater or substrates is high. This aligns with the results of Soda et al. 2012 that roots generally accumulate more metals than rhizomes. This also agrees with the finding of Singh et al. (2011) and Payus and Talip (2014), who detected more metals in the aerial part of $O$. sativa $L$. in a study on heavy metal accumulation in $O$. sativa $L$. However, C. indica due to its low BCF can be used in rhizofiltration in systems treatment of wastewater as observed by Cule et al. (2016).

The TF value as an indicator of plant ability to translocate metals from roots to aboveground parts of plants was below 1 for the two plants. It indicates a weak metal translocation from the roots to shoots. In our study, the TF for $C$ indica was higher than that of $O$. sativa $L$. for all metals analyzed, an indication of higher metal mobility. O. sativa $L$. with lower TF (average TF $<0.5$ ) is suitable for phytostabilisation of heavy metals in the soil according to Korzeniowska and Stanisławska-Glubiak (2015) due to its TF value. $O$. sativa $L$. met the conditions for it to be used in phytostabilisation and have the potential for its use in phytoremediation. It was reported that $\mathrm{Mn}$ is a micronutrient required in O. sativa $L$ for tillering (Ibrahim et al. 2018), so it was well removed from the effluent. The low values of BCF and TF make $C$. indica more suitable for phytoremediation with reduced health risk compared to O. sativa $L$. Also, C. indica is grown more for ornamental purpose while $O$. sativa $L$. is grown for its paddy, which is part of the aboveground tissue.

\section{Conclusion}

The study showed the potential of the two tested plants for phytoremediation of piggery wastewater in a tropical climate. The HssF CW system planted with O. sativa L. outperformed the $C$. indica planted system in term of abatement of pollutants and other requirements of typical macrophytes like high growth rate, widely distributed root system, translocation of the accumulated heavy metals from roots to shoots, tolerance to the toxic effects of the pollutants, good adaptation to the environmental and climatic conditions but with no resistance to herbivores as fed. The study also revealed that both plants are useful for phytostabilization of soils and wastewater characterized by relatively low pollution content. The health risk involved in the planting of $\mathrm{CW}$ with $O$. sativa $\mathrm{L}$. and its higher $\mathrm{BCF}$ and metal accumulation in the above-ground tissue than that of $C$. indica, make the $C$. indica to be more suitable than the $O$. sativa $\mathrm{L}$. with the fact that $C$. indica is a perennial plant while $O$. sativa $\mathrm{L}$. is an annual plant. This also highlights the health risk associated with its future consumption by man and animals after it has been used in phytoremediation. Otherwise, it can be used as a mulching material, especially the wild $O$. sativa varieties.

\section{Acknowledgments}

The authors would like to express their gratitude to the staff of the environmental engineering laboratory and the students at Landmark University for their assistance during the fieldwork. We gratefully acknowledge the critical comments and corrections of respected reviewers whose comments and corrections improved this work considerably.

\section{Disclosure statement}

No potential conflict of interest was reported by the author(s).

\section{ORCID}

Davids O. Raphael (D) http://orcid.org/0000-0003-0720-5087

\section{References}

Adrados B, Sánchez OL, Arias CA, Becares EL, Garrido LA, Mas JO, Brix H, Morató J. 2014. Microbial communities from different types of natural wastewater treatment systems: vertical and horizontal flow constructed wetlands and biofilters. Water Res. 55:304-312. doi:10.1016/j.watres.2014.02.011.

Ali H, Khan E, Sajad MA. 2013. Phytoremediation of heavy metalsconcepts and applications. Chemosphere. 91(7):869-881. doi:10. 1016/j.chemosphere.2013.01.075.

APHA. 2005. Standard methods for the examination of water and wastewater. 21st ed. Washington, DC: American Public Health Association. p. 10-15.

Bhattacharyya P, Das S, Adhya TK. 2013. Root exudates of rice cultivars affect rhizospheric phosphorus dynamics in soil with different phosphorus statuses. Comm Soil Sci Plant Anal. 44(10):1643-1658. doi:10.1080/00103624.2013.769562.

Chen W, Chen Z, He Q, Wang X, Wang C, Chen D, Lai Z. 2007. Root growth of wetland plants with different root types. Acta Ecologica Sinica. 27(2):450-457. doi:10.1016/S1872-2032(07)60017-1.

Chen Y, Bracy RP, Owings AD. 2009. Nitrogen and phosphorus removal by ornamental and wetland plant in a greenhouse recirculation research system. Hort Science. 44(6):1704-1711.

Cule N, Vilotic D, Nesic M, Veselinovic M, Drazic D, Mitovic S. 2016. Phytoremediation potential of Canna indica L. in water contaminated with lead. Fresenesius Environmental Bulletin. 25(11): 3728-3733. 
Darajeh N, Idris A, Truong P, Abdul Aziz A, Abu Bakar R, Che Man H. 2014. Phytoremediation potential of vetiver system technology for improving the quality of palm oil mill effluent. Adv Mat Sci Eng. 2014;2014:683579. doi:10.1155/2014/683579.

Elemile OO, Raphael OD, Omole DO, Oloruntoba EO, Ajayi EO, Ohwavborua NA. 2019. Assessment of the impact of abattoir effluent on the quality of groundwater in a residential area of OmuAran, Nigeria. Envir Sci Europe. 31:16. doi:10.1186/s12302-0190201-5.

Girard M, Nikiema J, Brzezinski R, Buelna G, Heitz M. 2014. A review of the environmental pollution originating from the piggery industry and of the available mitigation technologies: towards the simultaneous biofiltration of swine slurry and methane. J Environ Eng Sci. 9(1):80-92. doi:10.1680/jees.2014.9.1.80.

Haghshenas-Adarmanabadi A, Heidarpour M, Tarkesh-Esfahani S. 2016. Evaluation of horizontal- vertical subsurface hybrid constructed wetlands for tertiary treatment of conventional treatment facilities effluents in developing countries. Water Air Soil Poll. 227(1):28. doi:10.1007/s11270-015-2718-6.

Haritash AK, Sharma A, Bahel K. 2015. The potential of Canna lily for wastewater treatment under Indian conditions. Int J Phytorem. 17(10):999-1004. doi:10.1080/15226514.2014.1003790.

Huang X, Liu C, Gao C, Wang Z, Zhu G, Liu L, Lin G. 2013. Comparison of nutrient removal and bacterial communities between natural zeolite-based and volcanic rock-based vertical flow constructed wetlands treating piggery wastewater. Desal Water Treatm. 51(22-24):4379-4389. doi:10.1080/19443994.2012.747422.

Hussain A, Manjeeta P, Dubey S. 2019. Experimental study on accumulation of heavy metals in vegetables irrigated with treated wastewater. Appl Water Sci. 9(5):122. doi:10.1007/s13201-019-0999-4.

Ibrahim F, Anebi SI, Michael P. 2018. Response of rice (Oryza sativa) to the application of manganese in Makurdi, Benue State, Nigeria. JHPR. 4:17-24. doi:10.18052/www.scipress.com/JHPR.4.17.

Idris SM, Jones PL, Salzman SA, Croatto G, Allinson G. 2012. Evaluation of the giant reed (Arundo donax) in horizontal subsurface flow wetlands for the treatment of dairy processing factory wastewater. Environ Sci Pollut Res. 19(8):3525-3537. doi:10.1007/ s11356-012-0914-0.

Karczewska A, Lewińska K, Gałka B. 2013. Arsenic extractability and uptake by velvetgrass Holcus lanatus and ryegrass Lolium perenne in variously treated soils polluted by tailing spills. J Hazard Mater. 262: 1014-1021. doi:10.1016/j.jhazmat.2012.09.008.

Klink A, Macioł A, Wisłocka M, Krawczyk J. 2013. Metal accumulation and distribution in the organs of Typha latifolia $L$ (cattail) and their potential use in bioindication. Limnological. 43(3):164-168. doi:10. 1016/j.limno.2012.08.012.

Korzeniowska J, Stanislawska-Glubiak E. 2015. Phytoremediation potential of Miscanthus $\times$ gigantea and Spartina pectinata in soil contaminated with heavy metals. Environ Sci Pollut Res. 22(15): 11648-11657. doi:10.1007/s1135 6-015-4439-1.

Lai W-L, Wang S-Q, Peng C-L, Chen Z-H. 2011. Root features related to plant growth and nutrient removal of 35 wetland plants. Water Res. 45(13):3941-3950. doi:10.1016/j.watres.2011.05.002.

Lee S, Maniquiz MC, Kim LH. 2010. Characteristics of contaminants in water and sediment of a constructed wetland treating piggery wastewater effluent. J Environ Sci. 2222(6):940-945. doi:10.1016/ S1001-0742(09)60202-3.

Madera-Parra CA, Peña-Salamanca EJ, Peña MR, Rousseau DPL, Lens PNL. 2015. Phytoremediation of landfill leachate with Colocasia esculenta, Gynerum sagittatum and Heliconia psittacorum in constructed wetlands. Int J Phytorem. 17(1):16-24. doi:10.1080/ 15226514.2013.828014.

Meira CMBS, de Oliveira R, Ceballos BSO, Coura MA, Nascimento RS. 2013. Warm season performance of horizontal subsurface flow constructed wetlands vegetated with rice treating water from an urban stream polluted with sewage. Afr J Biotech. 12(25):3992-3999. doi: 10.5897/AJB2012.2923.

Molinuevo-Salces B, Mahdy A, Ballesteros M, González-Fernández C. 2016. From piggery wastewater nutrients to biogas: microalgae biomass revalorization through anaerobic digestion. Renewable Energy. 96:1103-1110. doi:10.1016/j.renene.2016.01.090.

Ng CC, Boyce AN, Rahman M, Abas R. 2016. Phyto-assessment of soil heavy metal accumulation in tropical grasses. J Animal Plant Sci. 26(3):686-696.

Nishiuchi S, Yamauchi T, Takahashi H, Kotula L, Nakazono M. 2012. Mechanisms for coping with submergence and waterlogging in rice. Rice. 5(1):2. doi:10.1186/1939-8433-5-2.

Oyem HH, Oyem IM, Ezeweali D. 2014. Temperature, pH, electrical conductivity, total dissolved solids and chemical oxygen demand of groundwater in Boji-Boji Agbor/Owa area and immediate suburbs. Res J Environ Sci. 8(8):444-450. doi:10.3923/rjes.2014.444.450.

Payus C, Talip AFA. 2014. Assessment of heavy metals accumulation in paddy rice (Oryza sativa). Afr J Agric Res. 9(41):3082-3090.

Raphael OD, Ogedengbe K, Amodu MF. 2020. Effect of treated greywater irrigation and mulches on yield of Capsicum chinense under surface drip irrigation system. IOP Conf Ser Earth Environ Sci. 445: 012017. doi:10.1088/1755-1315/445/1/012017.

Raphael OD, Ojo SIA, Ogedengbe K, Eghobamien C, Morakinyo AO. 2019. Comparison of the performance of horizontal and vertical flow constructed wetland planted with Rhynchospora corymbosa. Int J Phytoremediation. 21(2):152-159. doi:10.1080/15226514.2018 1488809.

Raphael DO, Okunade DA, Ogedengbe K, Adekunle OA. 2020. Assessment of a batch-flow free water surface constructed wetland planted with Rhynchospora corymbosa (L.) Britton for campus greywater treatment. Environ Sci Pollut Res Int. 27(4):4275-4283. doi:10. 1007/s11356-019-07095-6.

Remy C, Corominas L, Hospido A, Larsen HF, Teodosiu C. 2017. Assessing environmental impacts and benefits of wastewater treatment plants. In: Lema JM, Suarez, S, editors. Innovative wastewater treatment \& resources recovery technologies: Impact on Energy, Economy and Environment. Vol. 437. London: IWA Publishing.

Schierano MC, Panigatti MC, Maine MA. 2018. Horizontal sub-surface flow constructed wetlands for tertiary treatment of dairy wastewater. Int J Phytorem. 20(9):895-900. doi:10.1080/15226514.2018.1438361.

Singh J, Upadhyay SK, Pathak RK, Gupta V. 2011. Accumulation of heavy metals in soil and paddy crop (Oryza sativa), irrigated with water of Ramgarh Lake, Gorakhpur, UP, India. Toxicol Environ Chem. 93(3):462-473. doi:10.1080/02772248.2010.546559.

Soda S, Hamada T, Yamaoka Y, Ike M, Nakazato H, Saeki Y, Kasamatsu T, Sakurai Y. 2012. Constructed wetlands for advanced treatment of wastewater with a complex matrix from a metalprocessing plant: bioconcentration and translocation factors of various metals in Acorus gramineus and Cyperus alternifolius. Ecol Eng. 39:63-70. doi:10.1016/j.ecoleng.2011.11.014.

Stefanakis AI, Tsihrintzis VA. 2012. Effects of loading, resting period, temperature, porous media, vegetation and aeration on the performance of pilot-scale vertical flow constructed wetlands. Chem Eng Journal. 181:416-430.

Subhashini V, Rani C, Harika D, Swamy AVVS. 2013. Phytoremediation of heavy metal contaminated soils using Canna indica. Int J App Biosci. 1(1):9-13.

Subhashini V, Swamy AVVS. 2014. Phytoremediation of metal (Pb, Ni, $\mathrm{Zn}, \mathrm{Cd}$ and $\mathrm{Cr}$ ) contaminated soils using Canna indica. Curr World Environ. 9(3):780-784. doi:10.12944/CWE.9.3.26.

Thakur S, Singh L, Ab Wahid Z, Siddiqui MF, Atnaw SM, Din MFM. 2016. Plant-driven removal of heavy metals from soil: uptake, translocation, tolerance mechanism, challenges, and future perspectives. Environ Monit Assess. 188(4):206. doi:10.1007/s10661-016-5211-9.

Tokhun N, Chuleemas BI, Ta-Oun M. 2010. Piggery farm wastewater: alternative solution for agriculture and soil fertility. Int J Environ Rural Dev. 1(2):58-61.

Udom IJ, Mbajiorgu CC, Oboho EO. 2018. Development and evaluation of a constructed pilot-scale horizontal subsurface flow wetland treating piggery wastewater. Ain Shams Eng J. 9(4):179-3185.

Velho VF, Mohedano RA, Filho P, Costa RHR. 2012. The viability of treated piggery wastewater for reuse in agricultural irrigation. Int Recycling Org Waste Agric. 1(1):10. doi:10.1186/2251-7715-1-10. 
Vymazal J. 2013. The use of hybrid constructed wetlands for wastewater treatment with special attention to nitrogen removal: a review of a recent development. Water Res. 47(14):4795-4811. doi:10.1016/ j.watres.2013.05.029.

WHO. 2006. Guidelines for the safe use of wastewater, excreta and greywater/World health organization V. 4 Excreta and greywater use in agriculture. France.1 (1):10-140.

Wurochekke AA, Harun NA, Mohamed RMSR, Kassim AHBM. 2014 Constructed wetland of Lepironia Articulata for household greywater treatment. APCBEE Proc. 10:103-109. doi:10.1016/j.apcbee.2014.10.025.

$\mathrm{Xu}$-Jie LU. 2013. Application of constructed wetlands for the nitrogen removal. J Civil Environ Eng. 3:108. doi:10.4172/2165-784X.1000e108.
Yap DW, Adezrian J, Khairiah J, Ismail BS, Ahmad-Mahir R. 2009. The uptake of heavy metals by Oryza sativa L.in Kota Marudu, Sabah, Malaysia. Amer Eur J Agric Environ Sci. 6(1): 16-19.

Zhang DQ, Jinadasa KBSN, Gersberg RM, Liu Y, Tan SK, Ng WJ. 2015. Application of constructed wetlands for wastewater treatment in tropical and subtropical regions (2000-2013). J Environ Sci. 30: 30-46. doi:10.1016/j.jes.2014.10.013.

Zhang F, Li Y, Yang M, Li W. 2012. Content of heavy metals in animal feeds and manures from farms of different scales in northeast China. Int J Environ Res Public Health. 9(8):2658-2668. doi:10. 3390/ijerph9082658. 